\title{
TEACHING WRITING THROUGHT DICTOGLOSS
}

\author{
Ratna Sari Dewi \\ (ratnasaridewi.72@gmail.com) \\ UIN Syarif Hidaytullah Jakarta
}

\begin{abstract}
The objective of this study is to help students in developing their ideas in writing due to their difficulties to arrange ideas. Although they do have ideas, they cannot structure their ideas well in their papers. Several factors could cause this problem such as lack of vocabulary and knowledge or strategies in arranging ideas in papers. Another factor is unclear explanation and insufficient guidance from the teachers. Based on literature review, dictoglos can be a guide for students to develop their ideas in writing. It is a teaching technique which incorporates various activities such listening, taking notes, discussing, and reconstructing which have some standard procedures and variations.
\end{abstract}

Key Words: teaching writing, dictogloss

\section{INTRODUCTION}

English as an international language has been known all over the world. People cannot deny it, because many countries use and learn the language. The fact shows that the language is used as a second or a foreign language in each country in the world. Many people learn it to get involved in the world globalization era, where English in written or oral form of communication is used.

Therefore, it is a must for people to learn English. Whether they are students, worker, or other occupations that they belong to, 
they must study English. It can be learned through learning at school, in a course, or in their own ways. People must learn the language skills in order to master English well. The journey of the learning could be similar to a child learning to walk where he may fall down to the floor and get up to stand again and learn to walk continuously so that he can walk well. It is also the same when we learn a language. We must start from listening, speaking, reading and writing. The four language skills should be learned continuously and patiently.

Writing as one of the language skill at any level of education that has to be mastered is rather difficult than other skills. Students feel difficult to arrange their ideas in papers. Actually they have ideas but it is hard for them to deliver it into their paper or they have many ideas but they cannot choose what ideas should be chosen to develop. It happens because they have lack of vocabulary, cannot arrange the ideas correctly, do not know how to develop their ideas. This could happen because there is no clear enough information from the teacher. It is also possible that the teacher do not teach well. In addition to teachers, it should be acknowledged that there are many other factors that cause the inability of students to write in English.

Because some problems above, the writer wants to give an alternative solution to overcome the problem that is an approach to teach writing. It is hoped that the students have ability to develop their ideas in writing. The approach is called Dictogloss. In this approach students is trained to write their elaboration of one idea or improve simply an idea or a topic chosen by a teacher or they choose it freely from their own.

\section{THE TEACHING OF WRITING}

There are many definitions of writing according to some experts. Hyland (2003) defines writing as a product constructed from the writer 's command of grammatical and lexical knowledge, and writing development is considered to be 
the result of imitating and manipulating model provided by the teachers. It means that writing is a product of grammatical knowledge. It should be delivered by teachers by manipulating and giving example to their students. Moreover, Raymond describes that writing is a way of remembering and a way of thinking as well. Writing makes words permanent, and thus expands the collective memory of human beings from the relatively small store that we can remember and pas on orally to the infinite capacity of a modern library.

Furthermore, Nunan (1991) illustrates that writing can be viewed as involving a number of thinking processes which are drawn upon in varied and complex ways as an individual composes, transcribes, evaluates, and revises. He also states that writing has evolved in societies as a result of cultural changes creating communicative needs which cannot be readily met by the spoken language. Raymond (1980) defines that writing needs a process of remembering and also thinking.

Besides, Barnet and Stubbs (1983) define writing as a physical act; it requires material and energy. And like most physical acts, to be performed fully, to bring pleasure, to both performer and audience. It means that in writing students need to prepare themselves physically in form of material and energy. In addition, Axelrod and Cooper (1985) said, writing is a complex process and such contains element of mystery and surprise. Writing does still more, it contributes to personal development. As students write, they become more potential thinkers and active learners.

From the explanation above, it can be concluded that writing appears as the result of cultural changes and needs memory to remember and think. In addition, it is also a long process which requires both time and energy. Writing is also a unique and surprised process. 
Before students learn how to write well, they have to build and hone their competency into two broad areas. The first is writing mechanics, and second is writing process. Each of the areas contains a number of sub skills. The areas will be discussed more in the following.

Writing mechanics involve spelling, vocabulary, grammar, and punctuation. It includes everything from physically producing text to spelling correctly and producing accurate grammar. In short, the explanation is as follow. First, students have to know Graphemic realization of writing; the symbolic understanding (symbols have meaning), alphabetic principle (letters represent speech segments, and memory for letters. In the part of spelling students have to realize the visual discrimination, finemotor skills (handwriting and typing.

Second, the students should understand sound-symbol connections and patterns, memory for regularly and irregularly spelled words, linguistic comprehension, memory for words, recognition and understanding of grammatical patterns, memory for syntactically correct patterns, and understanding application of semantic conventions.

While writing process needs generating and organizing information, of which planning and editing are part. In acquiring knowledge of the process of writing students should know the retrieve knowledge, how to plan text, construct the text, edit the text, and regulate the entire process of writing.

To understand and practice the knowledge of how to write well they have to be trained and to be given the situation by teachers in applying a kind of approach called dictogloss. It will be described in the following discussion.

\section{DICTOGLOSS}

Dictogloss is a teaching technique which incorporates various activities such as listening, taking notes, discussing, and 
reconstructing. It is the same with the idea from Jacobs (2003), he explains that text reconstruction task provides students with the opportunities to display both their knowledge of the content of the text as well as of the organizational structure and language features of the text. It means that dictogloss gives opportunities to the students to comprehend what they have heard in form of notes, discuss with their friends and teacher, and then rewrite what they have learned.

It can be said that dictogloss is an activity in the classroom where students need to reconstruct a text given by teacher through listening, writing a note of key words which are then will be used as a base for new construction.

Moreover, Wajnryb states that dictigloss is designed to draw the learners' attention to language form, it promotes negotiation of meaning as well as negotiation of form. In this case students can discuss the material with their friend whether in pair, group or other activities during the process of learning and teaching.

In addition, Murray (2001) adds that dictogloss is helping students to use their grammar resources to reconstruct a text and become aware of their shortcomings and needs. It can be described that dictogloss makes students to be more aware of their grammatical choice that they used to reconstruct their ideas about the text. Furthermore, dictogloss is a language teaching technique that is used to teach grammatical structures, in which students form small groups and summarize a target-language text.

From the statements above it can be concluded that dictogloss give students more opportunities to learn about grammatical rules of text and reconstruct the rules in a text and rebuild new vocabularies. Dictogloss has multi functions such as to develop students listening, writing and speaking skills. It also builds new vocabulary for the students, enhance grammar and 
discourse systems to complete the task.

According to Kidd (1992) there are four stage procedures in applying dictogloss. They are: (1) preparation, (2) dictation, (3) reconstruction, and (4) analysis and correction. In preparation stage, teacher introduces the topic of a passage interestingly and imaginatively which activates students' knowledge and their comprehension. After that students are organized into group of 4 or 5 . The second stage is dictation. In this session students are read twice or three times at normal speed about the text. At this occasion students have three stages opportunity. The first they are not allowed to write anything except listen to the text from the teacher. In the next step, student jot important words and phrases in order that they can reconstruct the text.

In the third stage, reconstruction, students try to reconstruct a version of the text from their shared resources. Both text interpretation and reconstruction depend heavily on cooperation among members in the group work. The last is analysis and correction. In this condition, different group text results are examined and compared to the target structure. It can be done in many ways, such as writing it on chalkboard. This will be led to understand the source of the errors. Similarly, Ellis (1992) states some procedures in dictogloss as following. First, the teacher reads the text to the students at normal speed while they take notes, second, students work in small groups to prepare a summary of their work using the correct grammatical structures, and finally each group presents their work to the rest of the class.

The following is a real example of doing the procedures. Students discuss a text about going to the Zoo. The teacher then explains the task, and reads a short text about Going to the Zoo to the class. And then the teacher repeats reading the text again, and then students take 
notes. Then in group students reconstruct the text. The last activity is each group presents their works to other groups.

To get more comprehension about dictogloss, here it will be explained some variations of dictogloss. The variations are based on Wajnryb's classfication. Teachers can use one or two variations in their teaching. They are negotiation, student-controlled dictation, student-student dictation, summaries, scrambled sentence, opinion, picture, and elaboration.

Negotiation. In this variation students discuss after each section of text has been read. The sections can be varied depend on the difficulty level of text to students' proficiency level. The steps in doing this are: first, students sit with a partner, face to face, students just listen to the text being read for the first time, students do not allow to write. During the second reading the teacher stops after each sentence or two. Second, each members of the group writes the pair's reconstruction. And finally students compare their reconstruction with the original procedure in step 4 of the standard procedures.

\section{Student-Controlled Dictation.} Firstly, in this variation students are free to ask the teacher to read and stop the text depend on their understanding of the text when the teacher read it for them. But it still needs consideration for the highest level students towards the lower level proficiency students. The class might want to have a rule that each student can only say "please stop" one time. It is to avoid over control from different level students. Secondly, there is a partner conference. Next, teacher asks them to bring in texts to use for dictation or nominate topics.

\section{Student-Students Dictation.}

This variation can be done by students after they become familiar with the standard procedure of dictogloss. A text is probably longer than the usual one. The text is divided into four or five sections. Some students have the same 
sections and some student have different. Each student read the section they have been given and try to understand it. After that the students with the same section can initially meet in groups of three or four to read and discuss the meaning. Then in their original groups students take turns reading their section of the text as the teacher would for standard dictation while their group mates take notes. After that students work with their partner to reconstruct the text. Every group members plays the role as a teacher.

Summary. In this variation students only focus on the key idea of the original text. Step 1,2, and 3 are the same as in standard dictogloss. Students work with their partner to summarize the key points of the text. It can provide visual aids (sketch, flow, chart, photo, mind map) that represent some elements of the text. Moreover students can create their own visual aids to accompany their reconstruction as another means to demonstrate or promote a unique reconstruction.

Scrambled Sentence. This employs to raise the difficulty level of dictogloss and to focus students' attention on how texts fit together. In this variation teacher jumbles the sentences of a text before reading it to the students. Students reconstruct the text by creating what they have heard and then put it into logical order. When students analyze the reconstruction they will know that there is more than one possible correct order.

Elaboration. This variation of dictogloss is that students not only recreate a text but also to improve the text. In doing so, students have to elaborate or add adjectives and adverbs, examples, facts, personal experiences, and causes and effects. In this step students can work together whether in pair or group works consisted of more than two persons. In this activity students directly or indirectly can add their vocabulary. They can also change their works and share experiences. 
Students reconstruct the text. These can be factual, based on what students know about the topic of the text or research they do, or students can invent elaborations. In doing this step, students can develop and enhance their ideas.

Opinion. In this variation students give their opinion after they reconstruct the text. This opinion can be written down at various points in the text or at the end of the text. It seems to promote a kind of dialogue with the original authors of the text.

Picture. In this section students can complete a graphic organizer. The steps are: the teacher finds or writes a description of a drawing. The description is in detail, should include relevant vocabulary and concepts. Students listen to the description and do a drawing based on what they hear, then compare drawings with their partners and make one composite drawing per pair, compare with the original one, and alternatively students can reconstruct the description text read by teacher and then make a drawing.

Based on the explanation above it can be known that the are many variations in dictogloss in helping students to write in English. Some of the variations are dictogloss negotiation, student-student dictation, student-controlled dictation, dictogloss summaries, scrambled sentence dictogloss, elaboration dictogloss, and picture dictation.

\section{CONCLUSION}

Writing is one the skill that should be studied hardly by the students who learn English as a foreign or second language. In order that students can write well, teacher should know and apply approach, technique, method or strategy in their class. One of the techniques to be applied is dictogloss with some of its procedures and variations.

There are four procedures in applying dictogloss. They are: (1) preparation, (2) dictation, (3) reconstruction, and (4) analysis and 
correction. Text reconstruction task provides students with the opportunities to display both their knowledge of the content of the text as well as of the organizational structure and language features of the text. By applying this approach in the writing, it is hoped that students can develop their ideas in writing a text.

Finally dictogloss has eight valuable variations in helping and experiencing students to learn English, especially writing. The variations are dictogloss negotiation, student-student dictation, student-controlled dictation, dictogloss summaries, scrambled sentence dictogloss, elaboration dictogloss, dictogloss opinion and picture dictation.

It provides students to learn together with their friends and they can help each other in learning by doing reconstruction of a text after the teacher read it for the students. It also gives opportunities to the students to build up their new vocabularies. They know much about the grammatical structures.
Finally this technique can train students' English skills.

\section{REFERENCES}

Axelrod, Rise B. and Chooper, Charles R. (1985). The St. Martin's guide to writing. New York: St Martin's Press, Inc.

Barnet and Stubbs's. (1983). Practical guide to writing (4th ed). Canada: Brown Company.

Ellis, Rod. (1992). Second language acquisition and language pedagogy. Clevedon: Multiling ual Matters.

Hyland, Ken. (2003). Second language writing. Cambridge: Cambridge University Press.

Jacobs (1), George. (2003). Combining dictogloss and cooperative learning to promote language learning. The reading Matrix 3:4.

Kidd, R. (1992). Teaching ESL grammar through dictation. TESL Canada Journal (10/1).

McCutchen, D. (1988). Functional automaticity in children's writing. Written communication. 
Murray, S. Dictogloss. (2001). Wajnryb, R. (1986). Grammar Expanded. MET Journal, workout: The Dictogloss Volume 10 No 3, July.

Nunan, David. (1991). Language teaching methodology. New Approach, Listening Text Reconstruction Analysis. Sydney: Melting Pot Press. York: Prentice Hall.

Raymond, James. C. (1980). Writing is an unnatural act. New York: Harper and publisher. 
Ratna Sari Dewi

76| IJEE, Vol. 1, No. 1, 2014 